that many managed care drug plans overcharge members for generic drugs with copays of more than $\$ 5$ per 30 -day supply. For example, an announcement in mid-2002 trumpeted a program to promote generic drugs to physicians, pharmacists, and consumers but was associated with a 3-tier benefit design of $\$ 12$ (generic), \$20 (tier-2) and \$30 (tier-3) copays for a 30-day supply. ${ }^{37}$

The study by Nair, Ganther, Valuck, et al. adds to a thin literature on health plan member attitudes, other than satisfaction, related to prescription drug benefit plans. The study methods and interpretation of results should be reviewed carefully and critically. For example, the authors report statistically significant results that often appear to be an artifact of the large sample size and may have little if any practical significance, but, nevertheless, be of interest to some readers For example, the authors reported that 3-tier plan members compared to 2-tier plan members may be more likely to consult with friends or family members to obtain information related to the purchase of prescriptions, but not the pharmacist, or that 3-tier plan members may be more likely to obtain a second opinion from another physician. In all of these cases, the absolute differences in the mean scores are very small, less than 0.25 points on a 7-point scale. In survey research, ask 100 questions, and 5 will be statistically significant simply by chance, at an a priori $P$ value of 0.05. Survey enough respondents, and small differences in mean scores will produce statistically significant results.

\section{JMCP Peer Review and Editorial Process}

The quality of the Journal depends upon the collaborative work of authors, reviewers, and editors. Reviewers are often themselves authors, and more than 150 reviewers help to continuously improve the quality of the Journal. The bias management policy of the Journal is extensive and encompasses reviewers as well as authors. Members of the JMCP Editorial Advisory Board sometimes submit manuscripts for consideration, and these papers are treated no differently than any other manuscript.

All manuscripts submitted for consideration in the Journal undergo a prereview screen to protect reviewers from work associated with a paper that, due to a fundamental flaw in research design or insufficient relevance to readers, cannot be revised sufficiently to earn publication in the Journal . This prereview process is generally completed within 2 weeks of receipt of the manuscript. After passing the prereview process, each manuscript is sent to at least 3 independent reviewers, selected based upon expertise in one or more areas that are the principal subjects of the manuscript. All reviews are conducted under masking of author names and affiliations. Anonymity is the cornerstone of critical, scholarly review.

The JMCP bias management policy applies to all persons, regardless of their affiliation. In this issue of the Journal, the chairperson of the Editorial Advisory Board, Marvin D. Shepherd, PhD, collaborated with another researcher, Patricia Harrington, to write a subject review on the very timely matter of the transition of drugs from prescription to availability over-the- counter (OTC). In this case, 3 expert peer reviewers agreed unanimously that the manuscript should be published, and the authors revised the manuscript according to all reviewer suggestions. The mission of JMCP is to provide reliable and timely information to assist managed care pharmacists in their efforts to maximize value for money and improve the quality of patient care.

Frederic R. Curtiss, PhD, RPh, CEBS, Editor-in-Chief

\section{REFERENCES}

1. Winslow R, McGinley L, Adams C. States, insurers find prescriptions for high drug costs. Wall Street J. September 11, 2002:A1,A8.

2. Winslow R. Kaiser's experiment with generics. Wall Street J. September 11, 2002:A8.

3. Calabrese DC, Baldinger SL. Dose-optimization intervention yields significant drug cost savings. J Managed Care Pharm. 2002;8(2):146-51.

4. Gee M, Hasson NK, Hahn T, et al. Effects of a tablet-splitting program in patients taking HMG-CoA reductase inhibitors: analysis of clinical effects, patient satisfaction, compliance and cost avoidance. J Managed Care Pharm. 2002;8(6):453-58.

5. National Committee on Quality Assurance. The state of health care quality: Available at: http://www.ncqa.org/Communications/State\%200f\% 20Managed\%20Care/SOHCREPORT2002. Accessed October 3, 2002.

6. Expert Panel on Detection, Evaluation, and Treatment of High Blood Cholesterol in Adults. Executive summary of the third report of the National Cholesterol Education Program (NCEP) Expert Panel on Detection, Evaluation, and Treatment of High Blood Cholesterol in Adults (Adult Treatment Panel III.) JAMA. 2001;285(19):2486-97. Full ATP II guidelines available at: http://www.nhlbi.nih.gov/guidelines/cholesterol/index.htm. Accessed October 3, 2002.

7. Wolfe B, del Rio E, Weiss SL, et al. Validation of a single-patient drug trial methodology for personalized management of gastroesophageal reflux disease. J Managed Care Pharm. 2002;8(6):459-68.

8. Reuters Health. New York. May 16, 2002.

9. Multiple Sclerosis Council for Clinical Practice Guidelines. Disease-modifying therapies in multiple sclerosis. Evidence-based management strategies for disease-modifying therapies in multiple sclerosis. Paralyzed Veterans of America; 2001.

10. Lublin FE, Reingold SC. Defining the clinical course of multiple sclerosis: results of an international survey. Neurol. 1996;46:907-11.

11. Rudick RA, Cohen JA, Weinstork-Guttman B, et al. Management of multiple sclerosis. New Engl J Med. 1997;1604-11.

12. Drug Facts and Comparisons, Clinisphere version. Facts \& Comparisons. September 2002.

13. Ollendorf DA, Jilinskaia E, Oleen-Burkey M. Clinical and economic impact of glatiramer acetate versus beta interferon therapy among patients with multiple sclerosis in a managed care population. J Managed Care Pharm. 2002;8(6):469-76

14. Drug Facts and Comparisons, Clinisphere version. Facts \& Comparisons. September 2002.

15. www.fda.gov/OTC+Prilosec. Accessed October 10, 2002.

16. Harrington P, Shepherd MD. Analysis of the movement of prescription drugs to over-the-counter status. J Managed Care Pharm. 2002;8(6):499-508

17. Harris G. As a patent expires, drug firm lines up pricey alternative. Wall Street J. June 6, 2002:Al,Al0

18. Drug Price Competition and Patent Term Resotration Act (HatchWaxman), Public Law No. 97-417, 21 USC \$355(j) (1984).

19. Naik G. For AstraZeneca, ruling on patents will be critical. Wall Street J. September 10, 2002:C1,C3 


\section{Editorial}

20. DeBaise C. AstraZeneca has victory in ruling on drug patent. Wall Street J October 14, 2002:B4.

21. Armstrong D, Zimmerman A. Drug makers find new way to push pills. Wall Street J. June 14, 2002:B1,B4

22. Ukens C. Consumer ads here to stay, with impact on everyone: IMS. Drug Top. June 1999;21:25.

23. Glasgow C, Schommer JC, Gupta K, Pierson K. Promotion of prescription drugs to consumers: case study results. J Managed Care Pharm. 2002; 8(6):512-18.

24. Beatty S. TV gets most drug-ad spending, but magazines have equal impact. Wall Street J. January 14, 1999:B8.

25. Levy S. New survey finds public more aware of DTC Rx ads. Drug Top. August 16, 1999:1

26. The Green Sheet. December 10, 2001:3,4

27. The Henry J. Kaiser Family Foundation. Understanding the effects of direct-to-consumer prescription drug advertising. 2001; November. Available at: http://www.kff.org/content/2001/3197/DTC\%20Ad\%20Survey.pdf. Accessed October 14, 2002.

28. O'Connell V. Drug requests are more specific-FDA survey says doctors often prescribe the brands consumers name from ads. Wall Street J. April 15, 2002:B4.
29. Karhold K. New groups seek remedy to drug ads. Wall Street J. June 22 , 2000:B16

30. O'Connell V. Drug requests are more specific-FDA survey says doctors often prescribe the brands consumers name from ads. Wall Street J. April 15 2002:B4.

31. Young D. Studies show drug ads influence prescription decisions, drug costs. Am J Health-Syst Pharm. January 1, 2002:14,16.

32. Curtiss FR. Drugs, PPOs, tiered cost-share for beneficiaries, and consumer preferences. J Managed Care Pharm. 2002;8(3):177.

33. Joyce GF, Escarce, JJ, Solomon, MD, Goldman DP. Employer drug-benefit plans and spending on prescription drugs. JAMA. 2002;288:1733-39.

34. Nair KV, Ganther JM, Valuck RJ, et al. Impact of multi-tiered pharmacy benefits on attitudes of plan members with chronic disease states. J Managed Care Pharm. 2002;8(6):477-91.

35. Sloan FA, Connor CC. Effects of state reforms on health insurance coverage of adults. Inquiry. 1998;35:28-93.

36. Data were released by the U.S. Census Bureau on September 30, 2002, and reported in: Tieman J. Uninsured hits 41.2 million. Mod Healthcare. September 30, 2002:4.

37. Highmark and Trigon boost use of generic drugs for Medicare members. Drug Cost Management Rep. June 2002:9,10. 